\title{
The Use of Graphics to Communicate Findings of Longitudinal Data in Design-Based Research
}

\author{
Krista Francis, Michele Jacobsen, and Sharon Friesen \\ Werklund School of Education, University of Calgary, \\ Calgary, Canada
}

\section{kfrancis@ucalgary.ca; dmjacobs@ucalgary.ca; sfriesen@ucalgary.ca}

\begin{abstract}
Visuals and graphics have been used for communicating complex ideas since 1786 when William Playfair first invented the line graph and bar chart. Graphs and charts are useful for interpretation and making sense of data. For instance, John Snow's scatter plot helped pinpoint the source of a cholera outbreak in London in 1854 and also changed understandings of how germs were spread. While popular in the field of information graphics, rarely are graphs beyond the bar chart found in educational research articles. When present, the graphs do not necessarily enhance the findings of the data. Nor do educational research methods textbooks promote or instruct how to create visual representations to aid with interpretation and communication of findings. This paper attempts to address this void by sharing our processes for creating meaningful visual graphs for communicating multi-dimensional statistical findings more effectively. A working hypothesis was that carefully crafted visual graphics would convey our longitudinal research findings more effectively to broader audiences than existing forms. Three visuals were constructed from survey data three-year longitudinal design based research study of teacher and student learning in a one-toone laptop school. The study focused on learning designs that changed and improved student learning experiences and outcomes by adopting inquiry approaches to teaching that incorporate meaningful uses of technology. In field tests, our audiences found the visuals were useful for interpreting the findings. More and more frequently, academics are required to communicate their findings to broader audiences. A well-designed and well-constructed graph(ic) can provide a means for effective communication of complex, multi-dimensional statistical data. Such effective communication is beneficial for both an academic audience as well as for broader audiences.
\end{abstract}

Keywords: Visualizations, visual representations, descriptive quantitative data, longitudinal survey data

Material published as part of this publication, either on-line or in print, is copyrighted by the Informing Science Institute. Permission to make digital or paper copy of part or all of these works for personal or classroom use is granted without fee provided that the copies are not made or distributed for profit or commercial advantage AND that copies 1) bear this notice in full and 2) give the full citation on the first page. It is permissible to abstract these works so long as credit is given. To copy in all other cases or to republish or to post on a server or to redistribute to lists requires specific permission and payment of a fee. Contact Publisher@,InformingScience.org to request redistribution permission. 


\section{Introduction}

Alice was beginning to get very tired of sitting by her sister on the bank, and of having nothing to do: once or twice she had peeped into the book her sister was reading, but it had no pictures ... in it, 'and what is the use of a book,' thought Alice 'without pictures?' (Carroll, 1865/2004, p. 11)

The purpose of this paper is to present and discuss a multistage process for determining how to better represent and understand multivariate, longitudinal quantitative data using visuals to clearly communicate findings from a design based research study. We hypothesized that carefully crafted visualizations would convey our longitudinal research findings more effectively to broader audiences than do bar charts or line graphs. Visuals and graphics have been used to effectively communicate complex ideas since at least the $18^{\text {th }}$ century. Graphs and charts are useful and effective means for summarizing, interpreting, and making sense of data. For instance, John Snow's scatter plot helped pinpoint the source of a cholera outbreak in London in 1854 and also increased general understanding of how germs are spread. While popular in the field of information graphics, it is unusual for visual graphs beyond the bar chart to be used for reporting data in educational research. When visual graphs are used, it is not always the case that the graphs enhance the findings of the data. Few educational research methods textbooks promote or instruct researchers on how to create visual representations to aid with interpretation and communication of findings. This paper attempts to add to this gap by documenting and describing processes for creating meaningful visual graphs that can help to communicating statistical findings more effectively than a table or bar chart.

Reporting quantitative data in research requires an accurate portrayal of detailed methods and statistics. However, when communicating these results more broadly, tables of data are not always the best method for conveying research findings, especially those from research that has taken place over time. Statistical reporting without visual representations can limit the reader's access to understanding how and what changes have occurred in a longitudinal study over time. In contrast, a carefully designed graphic representation can enhance the interpretation of the data, provide an opportunity to understand how change has occurred, and make interpretation of the findings more accessible.

It is a challenge to find examples of meaningful graphics derived from quantitative data in education research. Journal articles that report quantitative results often do not include representative visuals or graphs (see Berlin \& White, 2012; Braden, 1996; Bulfin, Henderson, Johnson, \& Selwyn, 2014; de Villiers, 2007; McLaren, 2012; Yildiz, 2012). When graphs are included, these are often bar charts where the meaning of the data may not be immediately clear (Craig, Lang, \& Fisher, 2008; Shea \& Duncan, 2013). Quantitative research methods texts often describe how to present statistics accurately using alphanumerical characters, but do not provide instructions for representing statistics graphically (see Creswell, 2004; Huck, 2011). In this paper, we describe the value of presenting accurate statistical data using quality and meaningful graphic charts to facilitate the communication of results to a broader audience.

The creation of visual representations requires attention to a number of components, such as content, context, and construction. In this paper, the content was data drawn from a three-year longitudinal design-based study that examined the ways in which teachers design, work, and learn when they have continuous access to a laptop computer in a mobile, connected environment. The study also examined the ways in which students learn in a discipline-based inquiry environment; interact and collaborate with the teacher, peers, and others; and seek feedback from peers, outside audiences, teachers, and parents when they have continuous access to a laptop computer in a mobile, connected environment. 
Contextually, the data presented in this paper was drawn from a large set of data gathered during a longitudinal, cross-grade three year, design based research of one school's one-to-one laptop and professional learning initiative. Construction of the visual required the authors to choose an appropriate graphical form to capture several key variables in the study in the attempt to communicate changes in teacher and student learning over time. Early attempts at representation and the insights gained from explorations with different visualization forms influenced subsequent designs as we developed the means to visualize and communicate the complex longitudinal data from the survey more effectively than using a bar chart.

\section{Theoretical Background}

\section{Data Graphics}

There is a long history to using visualizations to make it easier to understand relationships in large volumes of data. Visualizations have been used to portray the results of analysis of large data sets in a useful and interesting manner. Playfair is often credited with pioneering the field of data graphics by displaying data using a comparative perspective (Tufte, 2001) . Playfair's 1786 time-series chart from Commercial and political atlas shows the balance of trade in England with imports and exports from Denmark and Norway, and clearly identifies a relationship of key interest, namely, the combination of exports and imports in favor of England (see Figure 1).

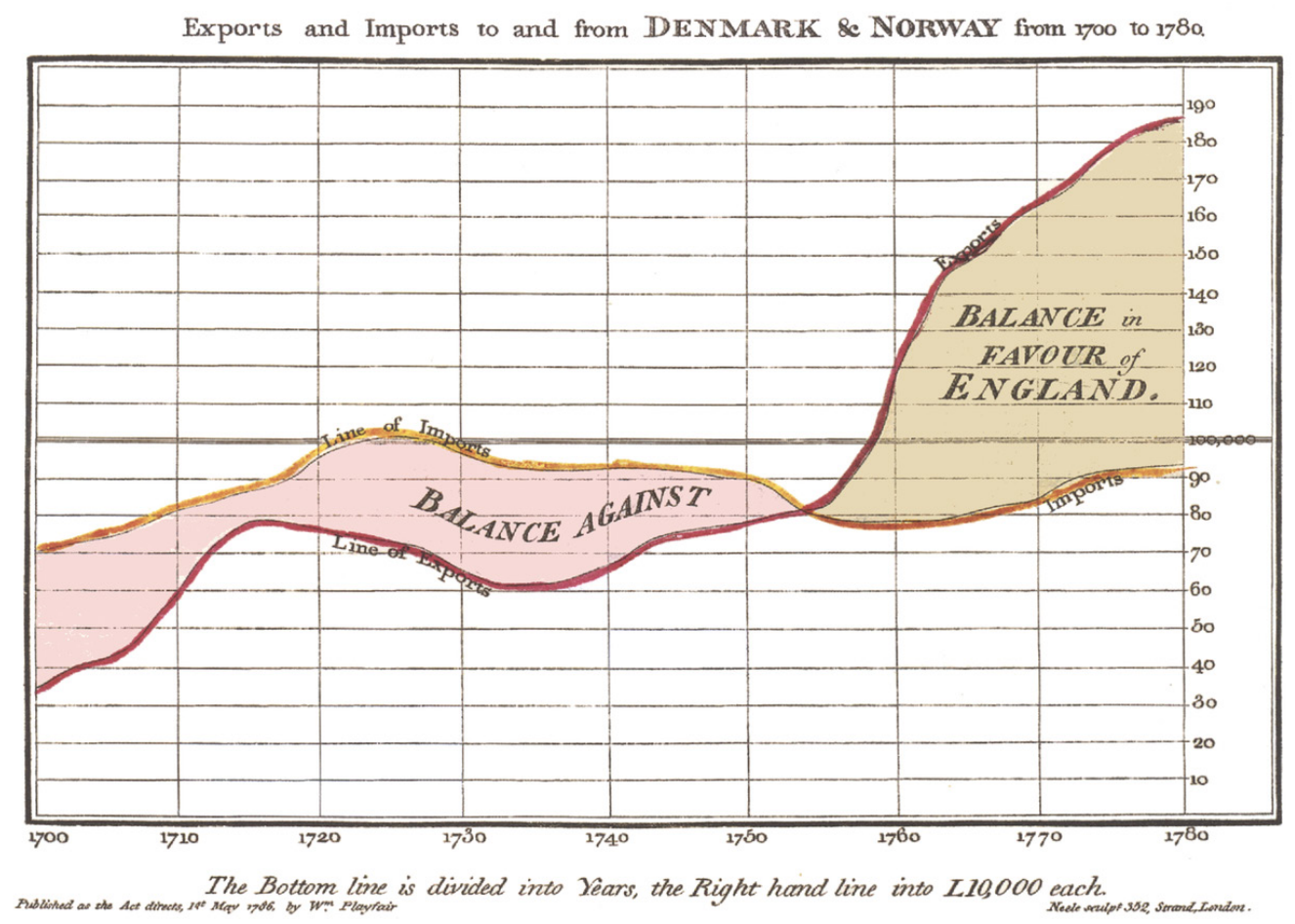

Figure 1: From Playfair's Commercial and political atlas. Source: "William Playfair," 2014.

Over two hundred years ago, Playfair invented four types of diagrams that are still popular and useful for summarizing and displaying data today: the line graph, the bar chart, the pie chart, and the circle graph. While Playfair's diagrams were useful for representing trends, John Snow's scatter plot was the first two-dimensional graph that displayed representations of Cartesian space (Friendly \& Denis, 2005). John Snow's scatter plot on a map of London (Figure 2) helped to 
pinpoint the source of a cholera outbreak in London in 1854 and helped to develop a broader understanding of how germs were spread (Rogers, 2013).

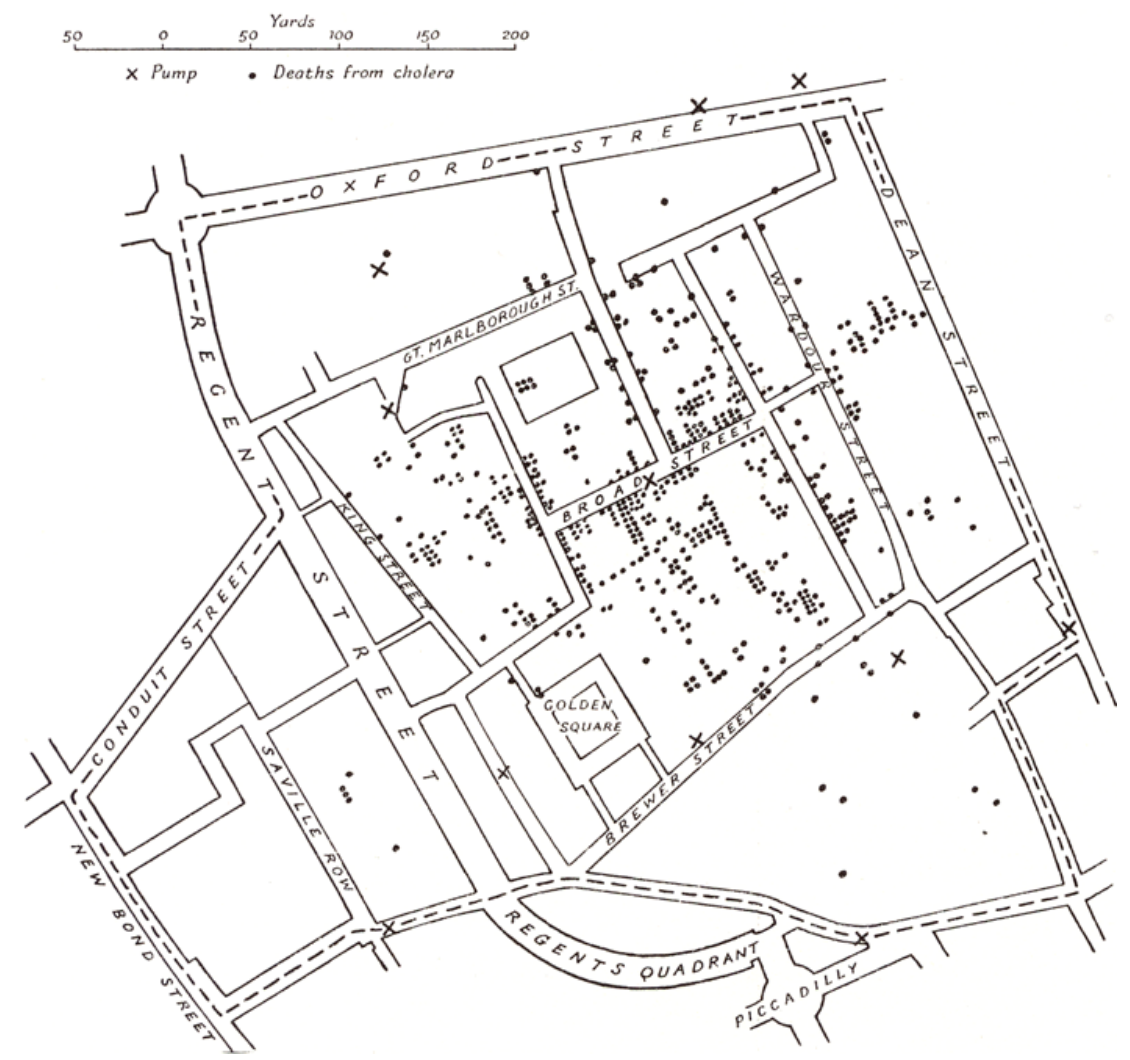

Figure 2. Cholera outbreak in London in 1854: Deaths marked with dots, Water wells marked with a 'x'. From Snow's On the mode of communication. Source: “John Snow," 2014.

In an information abundant world, graphical representations can help to convey and communicate increasingly complex data sets using animations. Gapminder, founded by Hans Rosling, is software that can be used to visually display time series statistical data and graph world trends over time. Gapminder includes a searchable function that enables public access to graphical animations on 517 data sets from organizations such as the UN and the OECD (Rosling, 2012a). Figure 3 is a Gapminder visual representation of the relationship between child mortality and income per person in 2012. Using time lapsed, graphical animations, Gapminder facilitates visual representations that connect multiple variables, such as income, health, life expectancy, religion, and child mortality rates (Rosling, 2006, 2012b).

The creation of meaningful graphics requires content, context, and construction (Unwin, 2008). In general, the content is what is plotted (i.e., the data) and the context involves where the data is from and its relevance to the research questions. The construction has many elements, including the graphical / visual form (i.e., barcharts, piecharts, histograms, dotplots, scatterplots, roseplots), color, and scale. The form of visual depends on the type of data to be displayed. Once the form is chosen, many more options can enhance or detract from the intended meaning, including scale and order. For example, a sort from largest to smallest can show a decreasing trend. Captions, annotations, and legends are used to explain the data used in the graphic. A balance between intext descriptions and the chart must be achieved. Color has potential to display complex data more effectively than shades of grey. All of these elements must come together to make the graphic aesthetically pleasing as well as informative (Unwin, 2008). Pousman, Stasko, \& Mateos (2007) argue that visualization systems help to "turn information into insight" (p. 1149). In the 
next section, the content, the context, and the construction processes that resulted in our visual representation of multivariate data are described.

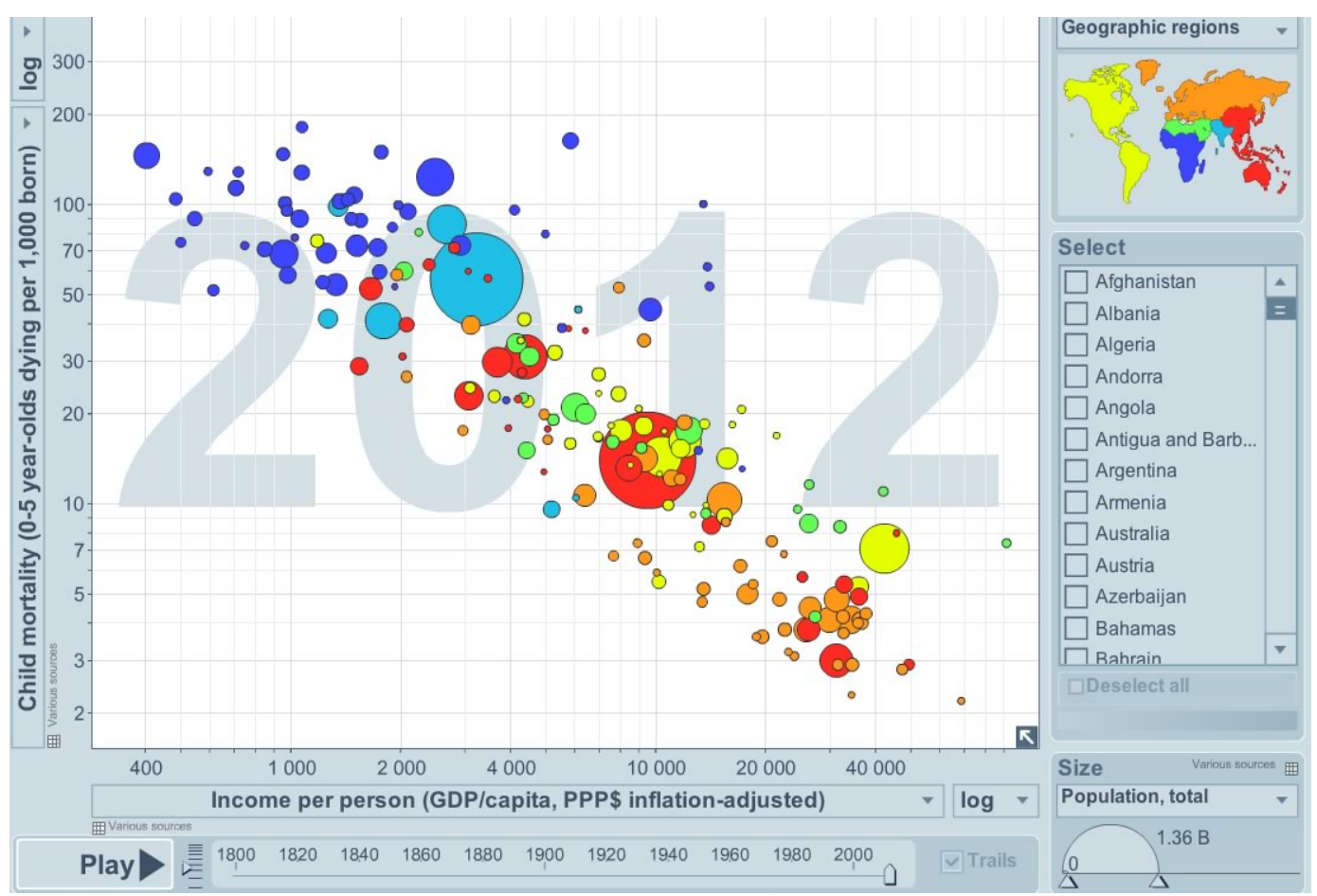

Figure 3: A Gapminder visual representation of child mortality and income per person data

\section{Method for Visual Data Representation}

\section{Content and Context}

What is plotted is the first and most important part of a visualization of data (Spence, 2006;

Unwin, 2008; Ware, 2012). The context provides relevance and situates the graphic within a larger field of meaning. Survey data from the three-year longitudinal design based research study of teacher and student learning in a one-to-one laptop school provides the content for the visualizations shared in this paper. The study focused on designs to change and improve teacher and student learning experiences and outcomes by adopting discipline based, inquiry approaches to designing learning experiences that incorporated in a one-to-one laptop environment. Consistent with design-based research (see Barab, 2006; Collins, Joseph, \& Bielaczyc, 2004; McKenney \& Reeves, 2013), a design solution (i.e., professional learning for teachers) was implemented in a gradual way with practitioners and data was collected from the complex learning system over time to study and to gain insight into the effectiveness and impact of the solution (on teachers and students). Data was also collected and analyzed in a formative manner to provide insights into next steps and the subsequent iterations of the solution. In this three-year study, several types of both quantitative and qualitative data was gathered from teachers and students in Grades 6 to 8 in order to better understand the impact from the implementation of an innovative approach to professional learning in a one-to-one personalized computing environment (see Jacobsen, Saar, \& Friesen, 2010). For the analysis of visual data representation in this paper, the descriptive statistics from the survey data from three sub-scales, (1) students' perceived technological ability, (2) 
students' frequency of use, and (3) teachers' perceptions of discipline-based inquiry in practice, are featured.

\section{Students' Perceived Technological Ability}

While the analysis and representation of relationships in numerical data are a feature of many studies, the interpretation of trends and relationships in data over time using only tables of data can be a challenge for both non-statisticians and statisticians alike. Identifying patterns and connections within complex data sets can be perplexing, and our desire to communicate how changes in both teacher and student learning occurred over time led us to the decision that a visual representation of the data to convey the complexity of relationships and the notion of time was needed. The requirements for good graphics in the construction of a diagram beginning with the choice of form (Spence, 2006; Unwin, 2008; Ware, 2012).

The data used to create the first visualization was drawn from a student survey designed to provide insights into the characteristics of learners, the impact of tasks on learning, and the levels and quality of student engagement. In response to a 22 item survey of technological ability, 108 students in 2007, 185 students in 2008, and 157 students in 2009 responded using a 4-point scale: (1) I can do this very well by myself, (2) I can do this with help from someone, (3) I know what this means but I cannot do it, and (4) I don't know what this means. Table 1 presents the mean responses to each technological ability survey item by year. While the table is an accurate summary of the descriptive statistics by item by year, it is a challenge to discern the patterns and trends in the data over time by just examining the results in the table.

Table 1: Students' Perception of Technical Ability Survey Results by Year

\begin{tabular}{|l|c|c|c|c|c|c|}
\hline & \multicolumn{2}{|c|}{2007} & \multicolumn{2}{c|}{2008} & \multicolumn{2}{c|}{ S009 } \\
$\begin{array}{l}\text { Q5: How well can you do each of } \\
\text { these tasks on a computer? }\end{array}$ & Mean & SD & Mean & SD & Mean & SD \\
\hline Open a file & 1.0 & 0.1 & 1.0 & 0.1 & 1.0 & 0.0 \\
\hline create and edit a document & 1.1 & 0.3 & 1.1 & 0.3 & 1.0 & 0.1 \\
\hline save a document & 1.0 & 0.0 & 1.0 & 0.0 & 1.0 & 0.0 \\
\hline print a document & 1.0 & 0.1 & 1.0 & 0.1 & 1.0 & 0.0 \\
\hline $\begin{array}{l}\text { collaborate with a group or team in } \\
\text { an online environment }\end{array}$ & 1.3 & 0.9 & 1.5 & 0.9 & 1.2 & 0.6 \\
\hline $\begin{array}{l}\text { download and edit a digital video } \\
\text { file }\end{array}$ & 1.6 & 0.8 & 1.6 & 0.8 & 1.3 & 0.6 \\
\hline $\begin{array}{l}\text { move files from one place to an- } \\
\text { other place on a computer }\end{array}$ & 1.1 & 0.4 & 1.1 & 0.5 & 1.1 & 0.2 \\
\hline create a podcast & 1.6 & 0.4 & 1.2 & 0.5 & 1.1 & \\
\hline create a webpage & 1.7 & 0.8 & 1.8 & 0.8 & 1.7 & 0.8 \\
\hline edit a graphic image & 1.8 & 0.9 & 1.6 & 0.9 & 1.3 & 0.6 \\
\hline use a spreadsheet to plot a graph & 1.6 & 0.9 & 1.5 & 0.9 & 1.4 & 0.7 \\
\hline Use interactive geometry software & 2.4 & 1.0 & 1.8 & 1.0 & 1.4 & 0.7 \\
\hline create a presentation & 1.1 & 0.4 & 1.1 & 0.4 & 1.1 & 0.5 \\
\hline
\end{tabular}




\begin{tabular}{|l|c|c|c|c|c|c|}
\hline & \multicolumn{2}{|c|}{$\underline{2007}$} & \multicolumn{2}{c|}{$\underline{2008}$} & \multicolumn{2}{|c|}{ S009 } \\
$\begin{array}{l}\text { Q5: How well can you do each of } \\
\text { these tasks on a computer? }\end{array}$ & & & & & Mean & SD \\
\hline create a simulation & 2.7 & 1.0 & 2.5 & 1.0 & 2.2 & 0.9 \\
\hline attach a file to an email message & 1.1 & 0.4 & 1.1 & 0.4 & 1.0 & 0.0 \\
\hline download music from the Internet & 1.4 & 0.8 & 1.5 & 0.8 & 1.3 & 0.7 \\
\hline $\begin{array}{l}\text { create a model using 3D software } \\
\text { such as SketchUp }\end{array}$ & 1.8 & 0.7 & 1.4 & 0.7 & 1.4 & 0.7 \\
\hline create a multimedia presentation & 1.6 & 1.0 & 1.7 & 1.0 & 1.3 & 0.6 \\
\hline draw original images & 1.5 & 0.8 & 1.5 & 0.8 & 1.3 & 0.6 \\
\hline edit digital audio files & 1.6 & 1.0 & 1.7 & 1.0 & 1.4 & 0.8 \\
\hline $\begin{array}{l}\text { convert a file to a different format } \\
\text { (iMovie to Quicktime, or m4a) }\end{array}$ & 1.6 & 0.7 & 1.4 & 0.7 & 1.1 & 0.4 \\
\hline publish my work on the Internet & 1.9 & 0.8 & 1.6 & 0.8 & 1.5 & 0.7 \\
\hline
\end{tabular}

\section{Choice of form}

To go beyond the tabular presentation of findings, we experimented with the many options for creating charts from data. At the most basic level, we wanted to compare the frequency of student's use of different types of technology over time. Bar charts can be useful for comparing categories of data. There were at least three issues with our first attempt at visualizing our data using a bar chart: 1) with 22 categories, it is difficult to differentiate among items, 2) the bar chart shows 'creating simulations' as the largest category (closest to 3 ), which is confusing because a larger mean actually reflects less ability, and 3) it is difficult to discern changes in the data over time. For example, students' perceived technological ability with creating simulations (mean = $2.7)$ is actually less than perceived ability with opening a file (mean $=1.0)$. Labeling the y-axis helps to covey the intended meaning without reversing the scale. Another reason we deliberately chose not to reverse the scale was because it did not help us to solve the third issue, which was the difficulty with discerning changes over the three years. The $y$-axis presents numerical results without an explanation of the meaning of this data over time. The third issue is that the continuity of changes over the same period of time is not obvious from a review of the bar chart (Figure 4). Given the three issues with using a bar chart to visualize our data, we decided to try another form.

Second, we created a line graph of data from the three years. Like the bar chart, the line graph can be used to compare the data over time (Figure 5); however, the line graph portrays dynamic data over time better than the bar graph (Figure 4). The connection of ordinal data by a line implies continuity of data, which is a misrepresentation of ordinality. However, in spite of the benefits of the line graph over the bar chart, we felt that the linear representation did not reflect the iterative nature of design solutions inherent within design research where the findings from each cycle inform the next stages of the design and intervention. 


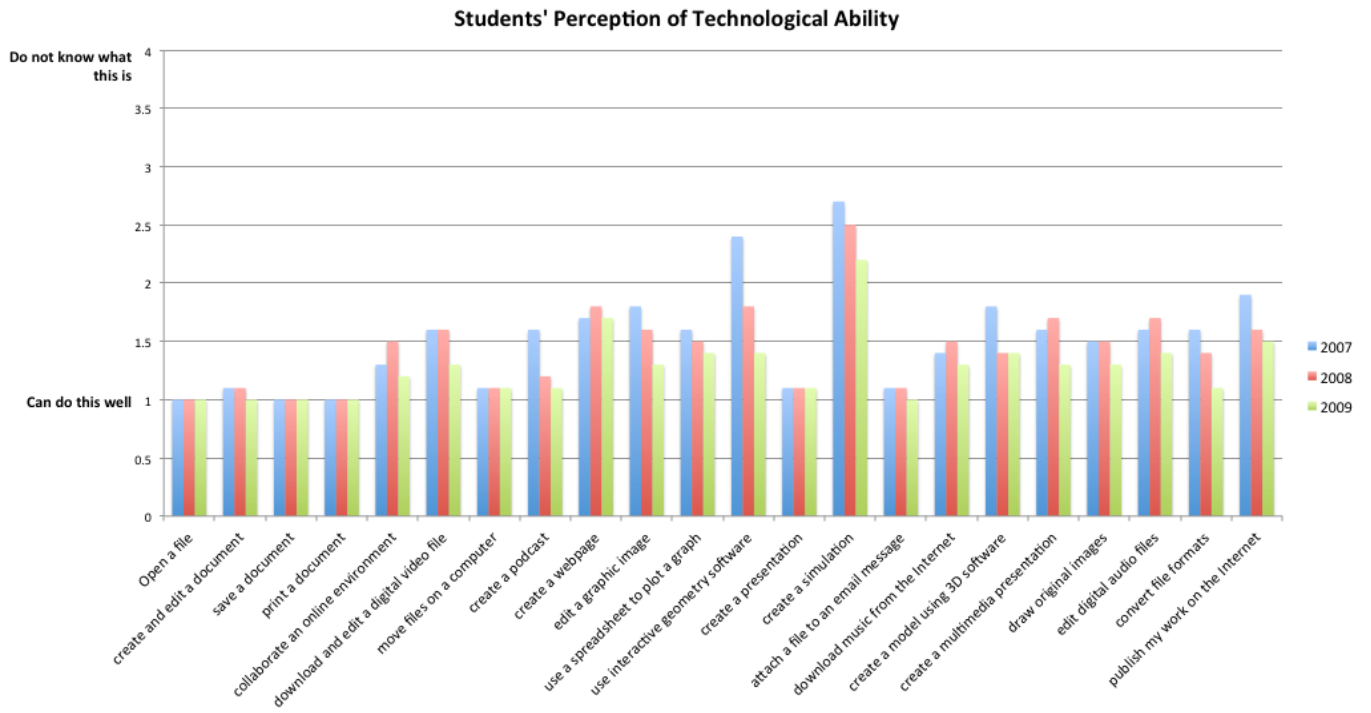

Figure 4: Bar chart representation of Students' Perception of Technological Ability survey data

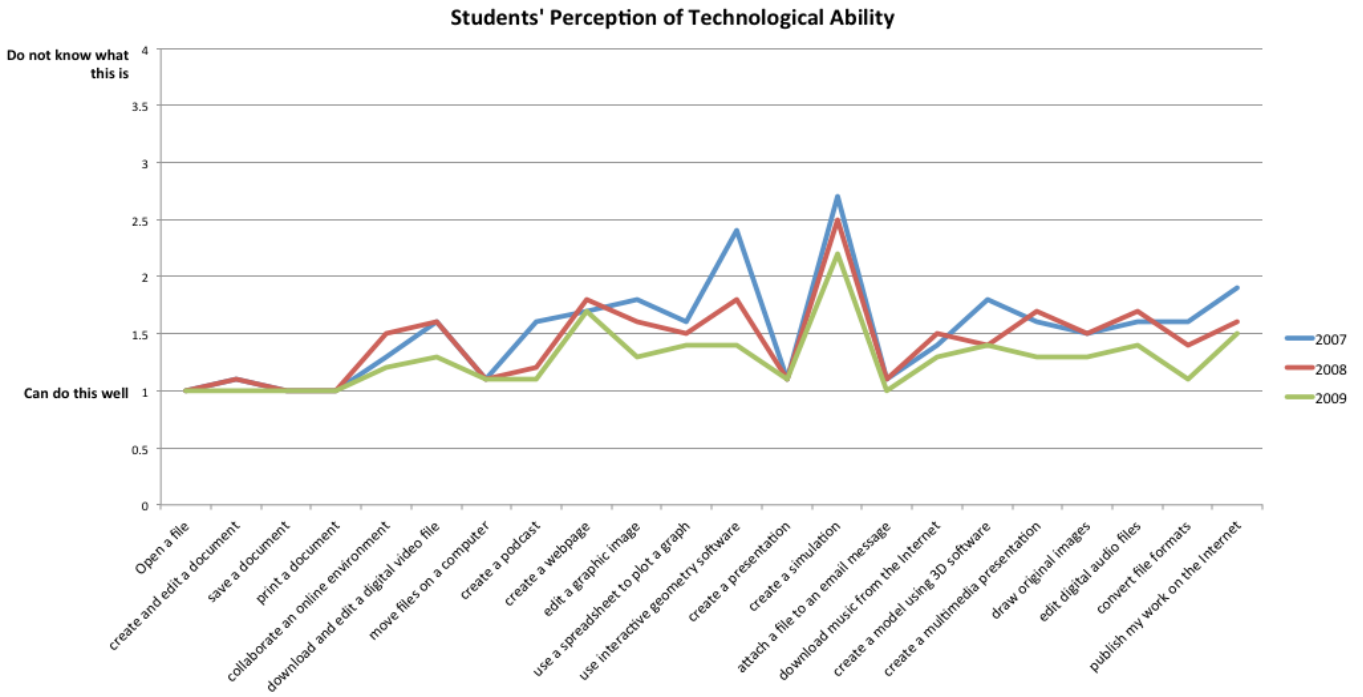

Figure 5: Line graph representation of Student's Perception of Technological Ability survey data

We decided to reject both the bar graph and linear forms in favour of a circular spider plot that we argue is more in line with the iterative nature of design research and representing changes in findings over time. The circular spider plot is useful for displaying longitudinal multivariate data and relationships. However, while we could use the circular spider plot to examine the different variables over time, we also wanted to look across variables to discern relationships and patterns in the system. So, once we decided the circular spider plot was a more suitable form of visualization for our data, we also decided to take the additional step to reorganize and classify the data to reflect the complexity and range of use of each of the technological tasks in the survey.

\section{Sorting and ordering}

Once a form and context is decided, Unwin (2008) describes how the order in which categories are presented can have a big effect on meaning. Each technological task on the survey instrument was sorted by complexity and range of use. By classifying and sorting the data from lowest to 
highest order of complexity, we provided another dimension by which we could sort and understand the data. To classify the data by level of complexity, each of the technologies referred to in the student survey was assigned a rank based on Lemke's and Coughlin's (2000) Range of Use chart (Figure 6).

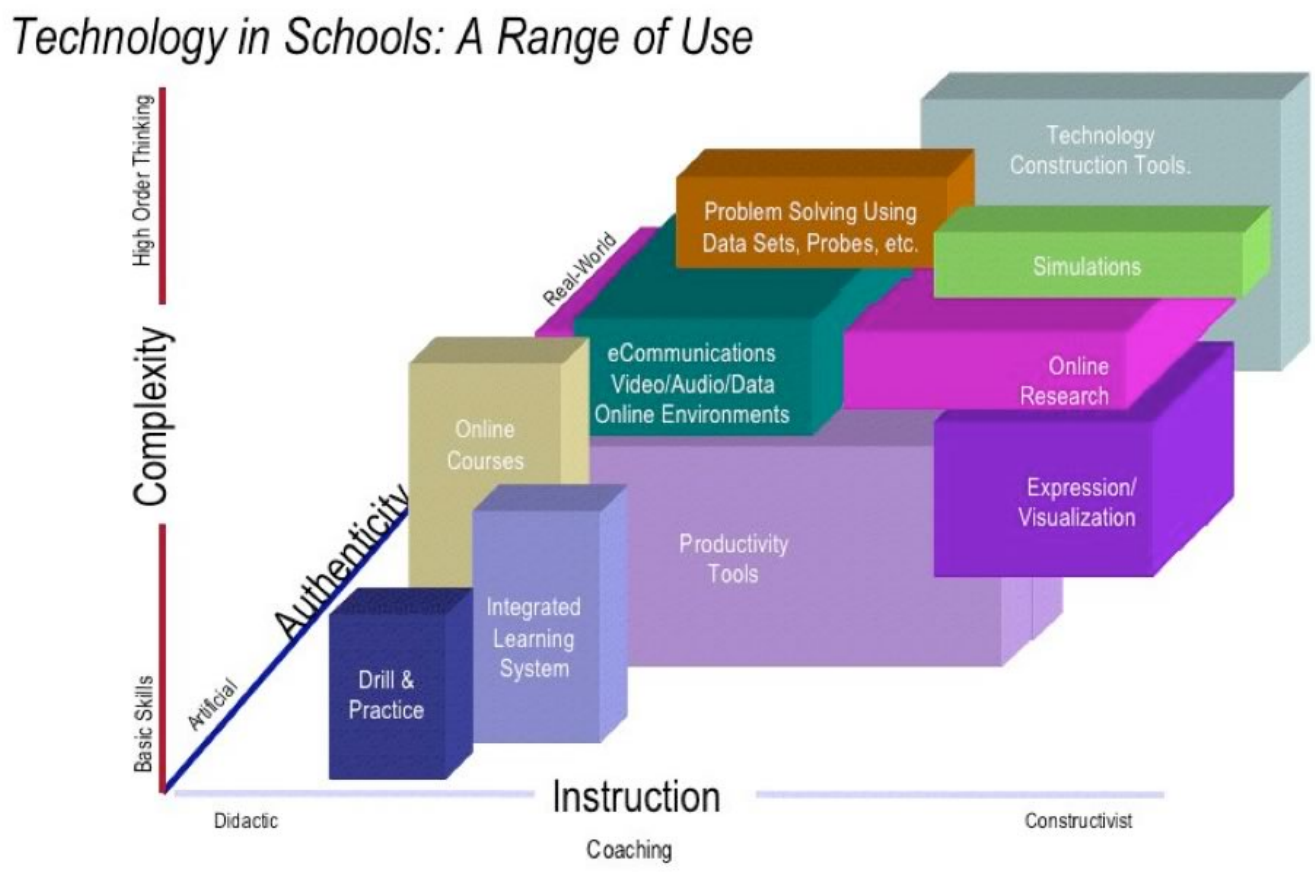

Figure 6: Lemke's (2005) Range of Use chart (used with permission)

We superimposed a numeric scale on Lemke's sliding scale of complexity and range of use. Each of the technological processes was assigned a rank in the order that the technology appeared on the diagonal (e.g., drill and practice was assigned 1 and data collection and probeware was assigned 10). Using this method, we assigned complexity rankings to the 22 technologies in the student survey.

Using the complexity rankings, the technologies were reorganized in ascending order by level of complexity. The resulting visual, a circular spider plot based on our choices of form and sort, was a good start to conveying a message consistent with the changes observed in the system (Figure 7). The spiraling effect of the data made it more clear that students perceived that they were most adept with low complexity technology tasks and least adept with higher complexity tasks using technology. For example, one can observe that students perceived a high level of technological ability with opening files, saving documents, and printing documents, which represents lower levels of complexity, and a low level of ability with creating a simulation, which represents a higher level of complexity using Lemke's (2005) scale. Data by technology task in subsequent years appears further out in the circle, which provides a visual representation and a more accessible interpretation of growth in students' perception of technological ability over time. For example, using the circular spider plot, one can observe that students' perception of their ability to create a simulation and use interactive geometry software increased each year from 2007 to 2009 , as did students' perceptions of ability with many other technology tasks. 


\section{Students' Perception of Technological Ability}

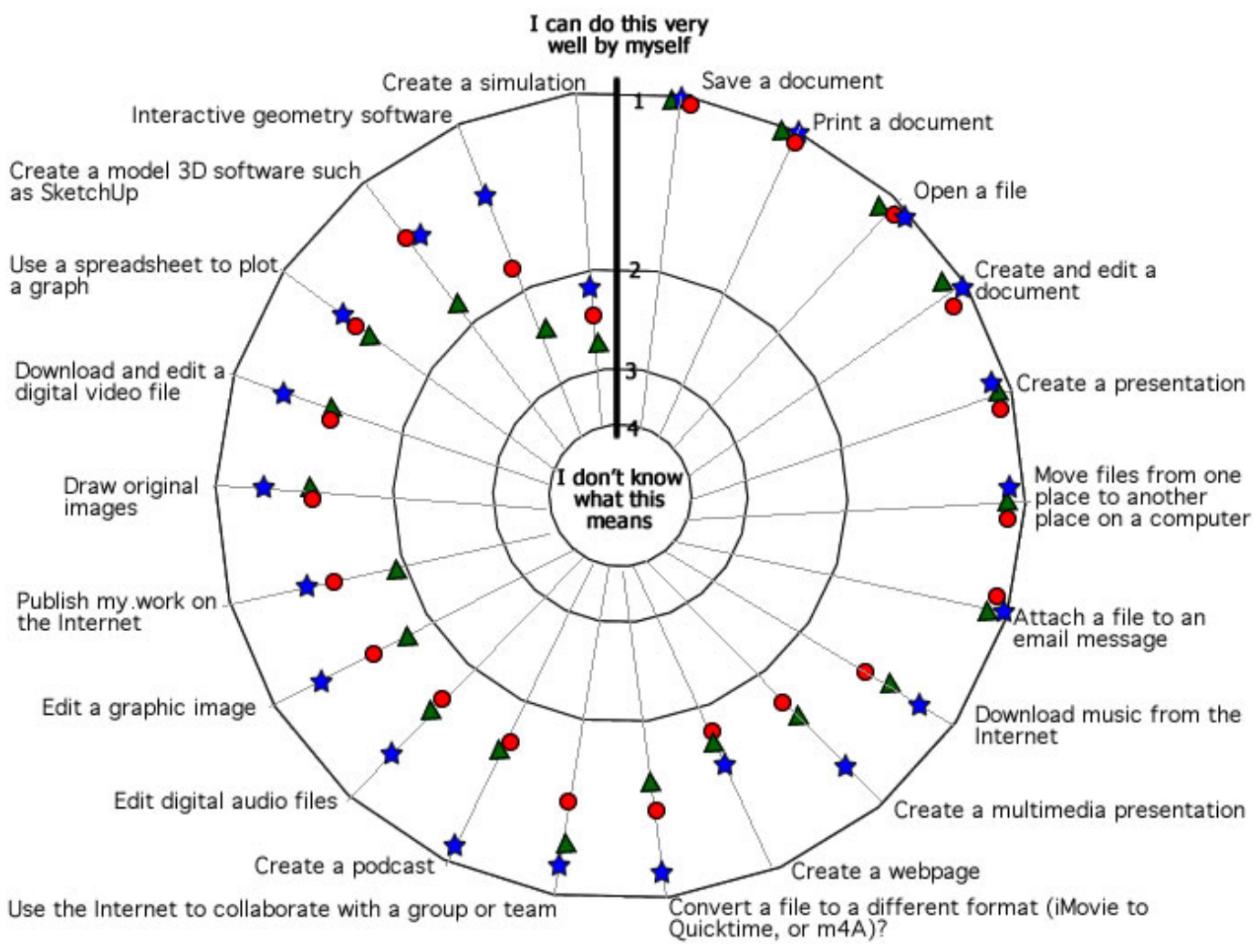

\begin{tabular}{|r}
2009 \\
$\quad 2008$ \\
$\Delta 2007$ \\
\hline
\end{tabular}

$2007-2009$

Figure 7: Circular Spider plot of Students' perception of technological ability from 2007 - 2009

\section{Overlaying statistical information}

The circular spider plot visualization of the data was closer to what we needed for a more accurate representation of our multivariate, quantitative data. However, we still believed that the visual impact of the circular spider plot was not sufficient. Working with the "Charts" feature in Excel was somewhat cumbersome; however, with some manipulation, the feature was able to handle all of the steps to working with the data to this point. Unable to add a statistical underlay to the graphic using Excel, we chose Fireworks to complete the graphic. To emphasize the difference in the complexity of the technologies from the survey, we added a statistical underlay to subdivide the complexities and represented this visually by varying the background of the form using a monochromatic gray scale color scheme. We then used Color Brewer (see http://colorbrewer2.org/) as recommended by Unwin (2008) to choose the background and data point color scheme for our final visualization. For the data points, we wanted to visually convey transitions in student's perceptions of technological ability and the complexity of technologies over time. We chose colors that would 'pop,' which both Spence (2006) and Ware (2012) refer to as pre-attentive processing because it occurs prior to consious awareness. Orange was the color chosen for the data points because it can convey movement without overpowering the image 
(Skyjie, 2012). The lightest orange tone was chosen for data from 2007 and the orange tone darkens with each year. The color gradient is use to better convey the uncurling of the spiral with time.

We reduced the text used to describe the technology tasks. Beyond the standard title and legend, we also added another caption to emphasise that the complexity of technology tasks increased clockwise. Figure 8 below is the final visual representation of the findings.

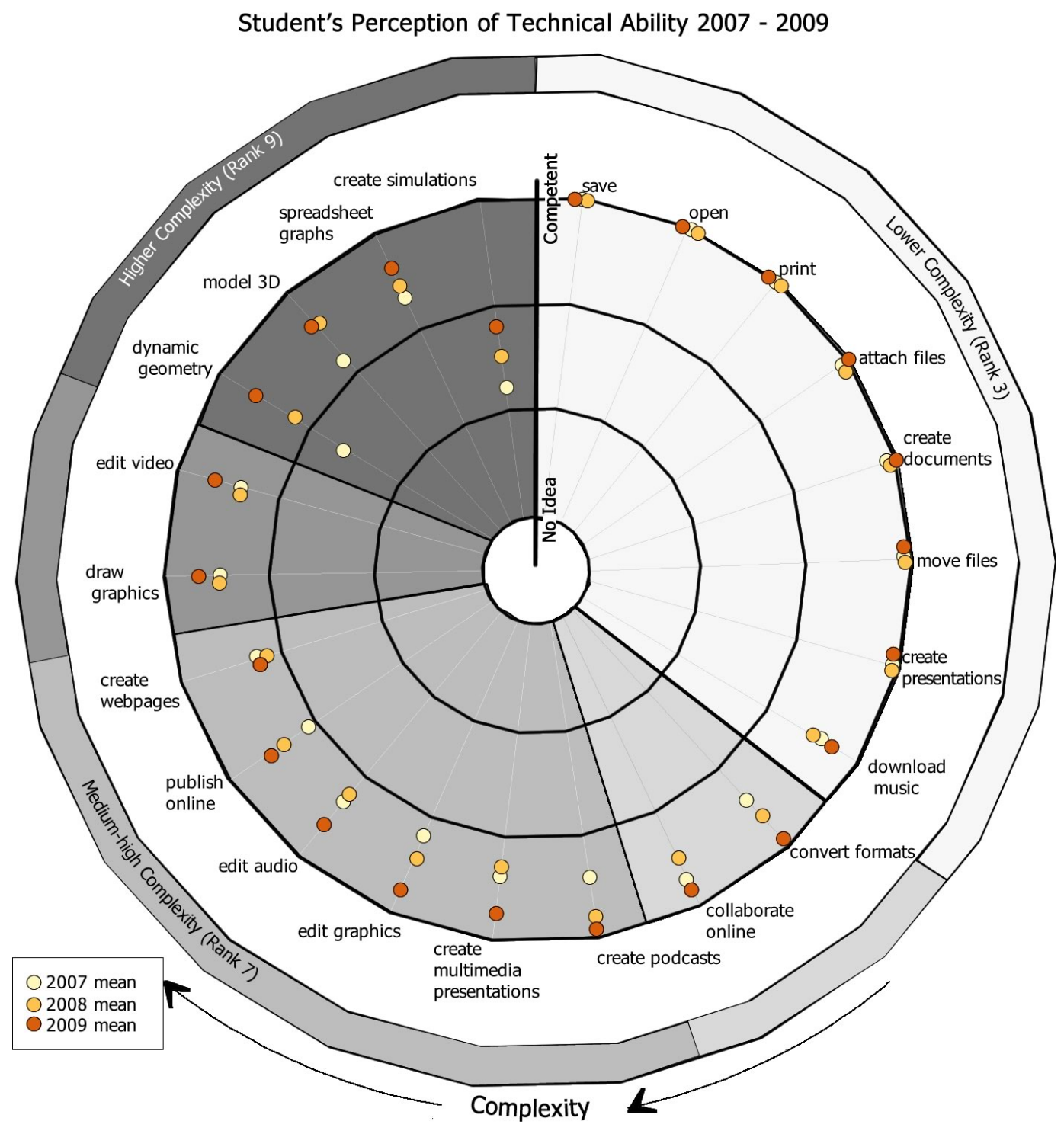

Figure 8: Final graphic of Students' Perception of Technical Ability survey data

\section{Explaining students' perception of technical ability}

The graphic demonstrates an uncoiling of the spiral as time progresses and as levels of complexity of technology tasks increase. In 2007, student responses indicated that they perceived competence with low complexity technology tasks, yet their perceived competency decreased as the complexity of the tasks increased. In subsequent years, students' perceived ability in more complex technology tasks increased. By 2009, student responses indicated they could create podcasts 
and multimedia presentations, edit graphics, audio, and video, and publish their work online. By 2009 , students perceived higher levels of ability with spreadsheets and graphs, and a more dramatic increase in perceived ability with dynamic geometry software, than in 2007.

\section{Students Frequency of Use}

The next visual we created was based on findings from the student survey of frequency of use of technology at school. The number of respondents was 108 in 2007, 186 in 2008, and 157 in 2009. The Likert response scale for technology use was (1) almost every day, (2) a few times each week, (3) between once a week and once a month, (4) less than once a month, and (5) never. See Table 2 in Appendix A for the tabular results of this survey. The same process for visualizing the findings using form, sort, and overlaying statistical information was used. Figure 9 is the final representation of the findings of the Students' Frequency of Use survey from 2007 to 2009.

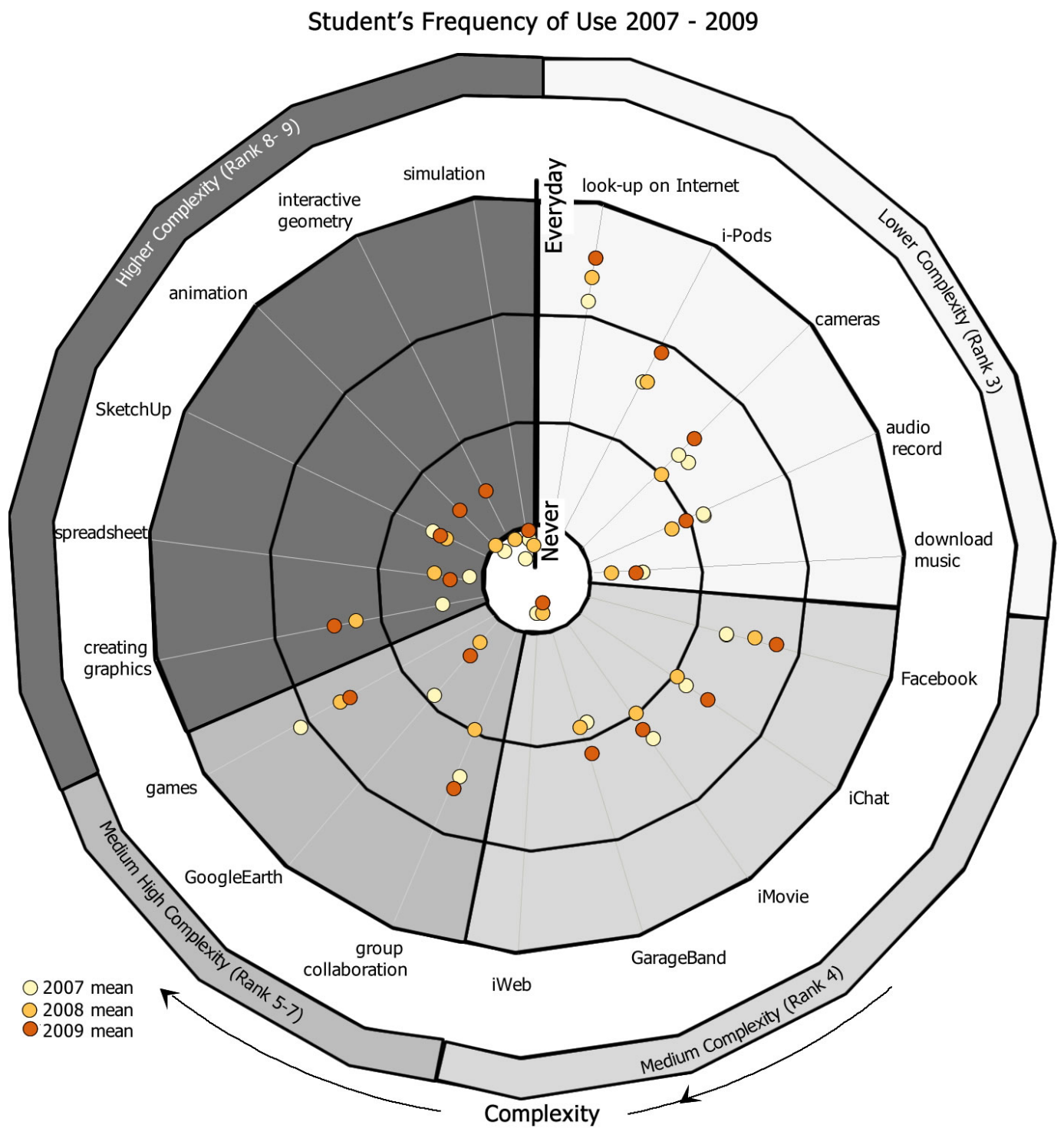

Figure 9: Graphic representation of Students' Frequency of Use survey data 


\section{Explaining students' frequency of use}

The graphic (Figure 9) demonstrates an uncoiling of the spiral of results as time progresses in a similar way to Figure 8. For example, in 2007, students reported frequent use of lower complexity technology tasks, yet their reported use decreased as the complexity of the technology task increased. In subsequent years, the frequency of students' use of more complex technology tasks increased. By 2009, students reported higher frequencies for creating graphics and animations, using interactive geometry software and creating simulations at school. This graphic tells a similar story to Figure 8; we content that the two visualizations make the patterns, trends, and relationships in the findings over time more accessible for interpretation and more clear than would a table or a bar chart form of representation.

\section{Teacher's Perceptions of Their Own Inquiry Practice}

The data used to create our third visualization was drawn from a teacher survey designed to provide insights into their perceptions of instructional designs and classroom practice. In 2007, a small number of teachers participated in the study and no survey was conducted. In 2008, 10 teachers participated in the study and completed the survey. In 2009, 9 teachers completed the survey (See Table 3 in Appendix B for the complete data). The survey consists of 39 items that poll teachers' perceptions of how well they incorporate Galileo Educational Network's (2014) five characteristics of teacher inquiry: (1) assessment, (2) active exploration and connecting with experts, (3) authenticity and academic rigour, (4) learning in the world, and (5) appropriate and creative use of technology. Assessment was described as ongoing, reflective, provides timely feedback, guides student learning, and teacher's instructional planning Authenticity is an inquiry into a question, problem, or exploration. An authentic inquiry has meaning to the students, might be tackled by an adult, provides opportunities to create or produce something that contributes to the world's knowledge, and requires a variety of roles and/or perspectives. An academically rigorous inquiry requires multiple approaches to engagement and representation of understanding, and leads students to build knowledge and deep understanding. Learning in the world takes learning activities and tasks beyond the confines of the classroom. Effective use of digital technologies is when technology is essential for the task, is chosen by students, and requires communication both inside and outside the classroom (Galileo Educational Network, 2014). Teachers responded to the survey items using a 4 point Likert scale: (1) I can do this very well by myself, (2) I can do this with help from someone, (3) I know what this means but I cannot do it, and (4) I don't know what this means.

A bar chart or table would not be an effective means to display two years of data for 37 survey items. Thus, we decided to use the circular spider plot form to display the teacher survey data. In our chart from the first year, we included detailed information. To show how each step of Unwin's (2008) processes helped us to better convey the meaning of the findings using a circular spider plot, our graphic from the first year is shown in Figure 10.

We noted some deficiencies and limitations in this visualization of the data, such as readability and accessibility (Figure 10). For example, the density of text obscures rather than highlights relevant survey findings and information. A variety of colours were used in an attempt to separate categories of inquiry and to make each distinguishable or easily relatable to the data. To make the findings of the survey more accessible and open to analysis and interpretation, the data was sorted by the 2008 means. This approach to sorting the data enabled us to organize the data points in ascending order and present findings in a circular arc within each inquiry category. While the new spiral plot (Figure 11) shows the items for which perceptions of inquiry were stronger, our first chart had too much information to convey the message as easily. 


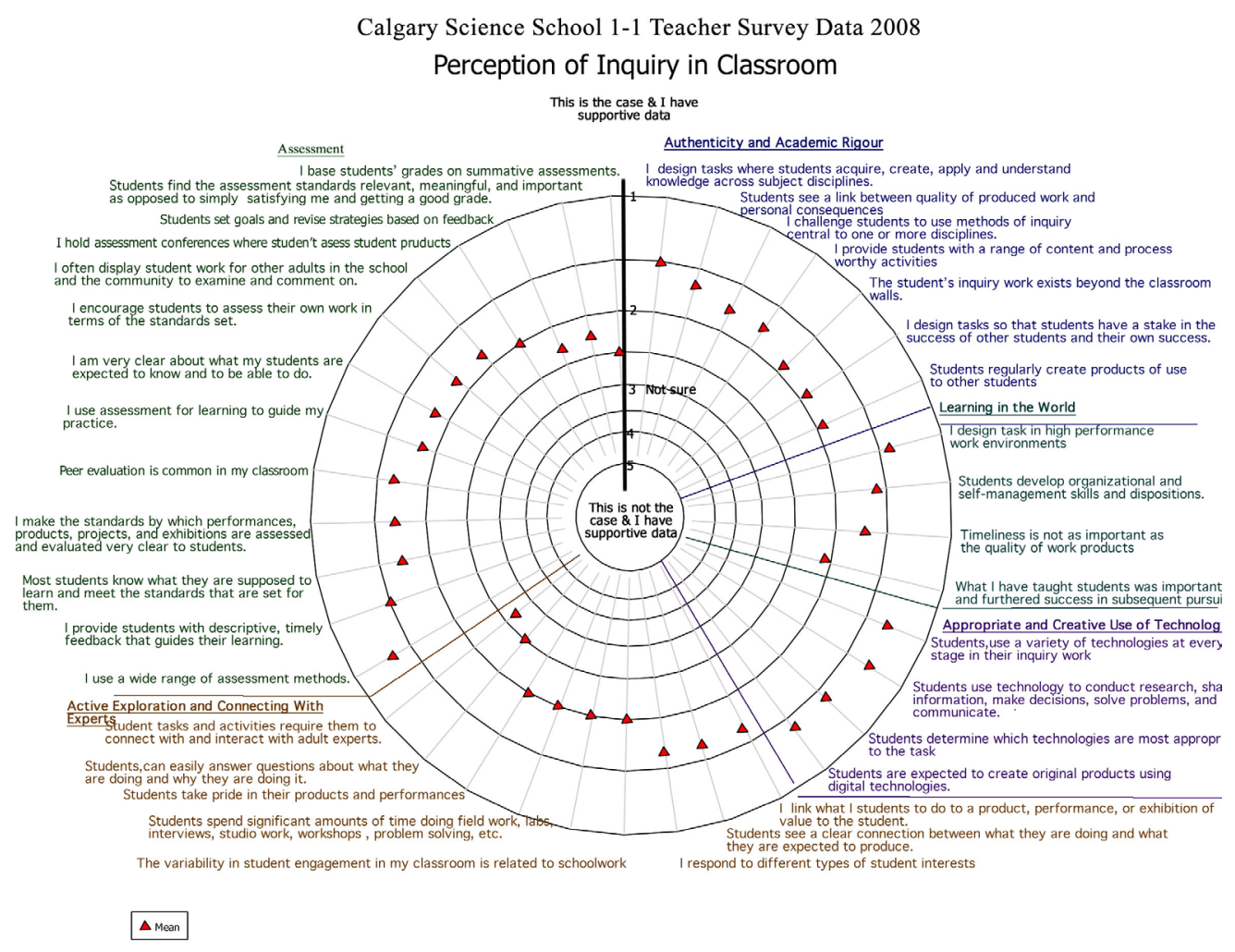

Figure 10: First representation of Teacher's Perception of Inquiry Data

To represent the findings from the final year of the study, we adapted Unwin's (2008) processes for creating a more effective and aesthetically pleasing graphic. First, we reduced the text density by replacing the entire survey questions with one descriptive word. Reducing the textual density of the annotations was the most dramatic change from first to second circular spider plot.

The second most dramatic change was to scale. Instead of using the area of the circle for the axis, we changed the axis to a measure of the radius. In other words, the circles are equidistance apart proportional to the Likert scale. This radius axis is a more accurate depiction of the Likert data (Figure 11).

\section{Overlaying statistical information}

To delineate the different aspects of inquiry represented by the survey items, we provided a sequential gray colour statistical underlay for each group of survey items. This sequential gray background layer distinguishes the five areas of inquiry, providing emphasis to each. A band around the circular scatterplot names and highlights each aspect of inquiry. The orange colour scheme for the calculated means helps to convey the changes in teachers' perceptions of their designs and instructional practices over time. 


\section{Perception of Inquiry in Classroom}

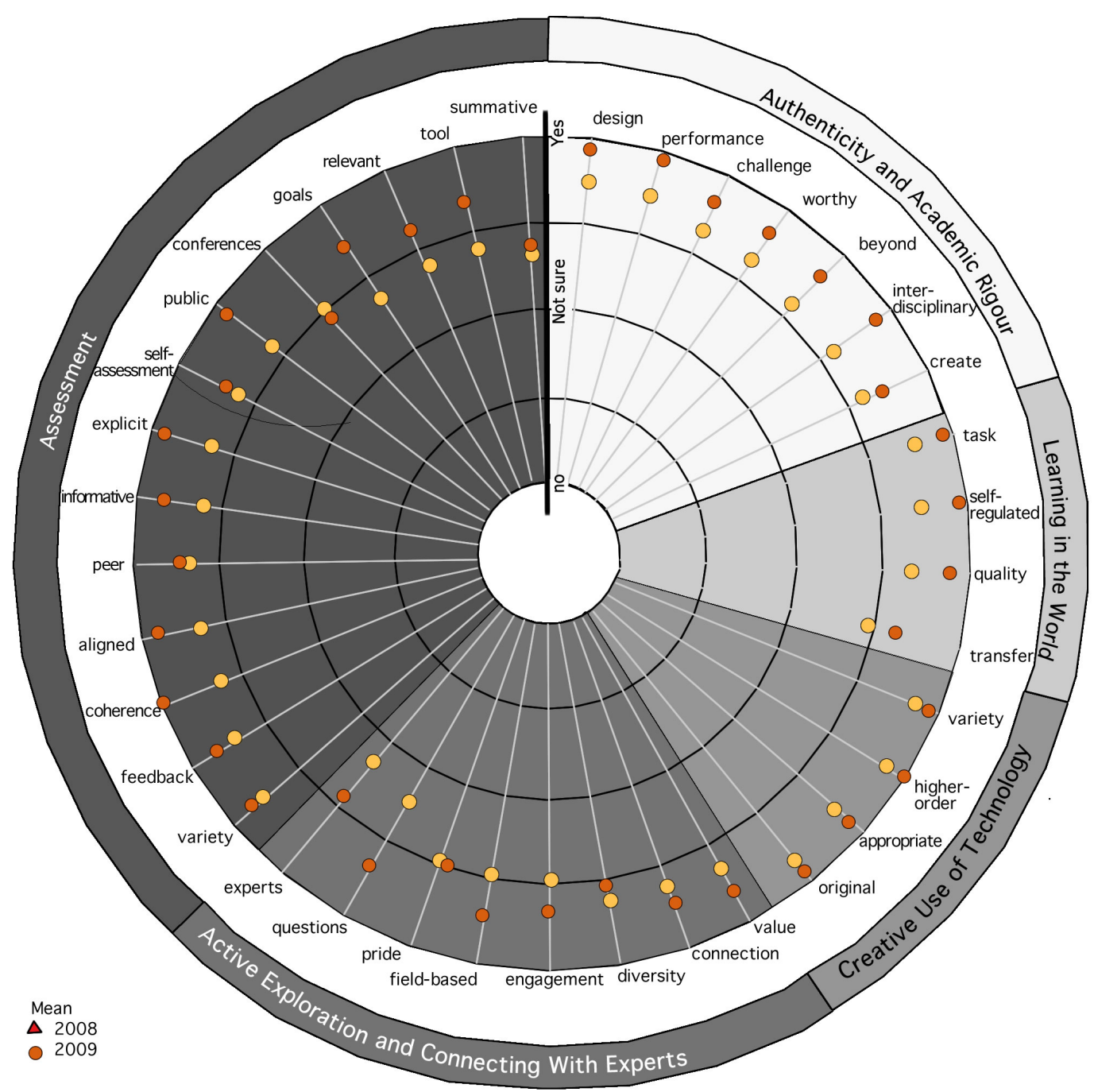

Figure 11: Revised representation of Teacher Inquiry data

\section{Explaining teacher inquiry}

The changes made from the first to the second visualization improve our ability to access and to understand the findings from the survey of teachers' perceptions of inquiry and task design. The viewer can observe changes in teacher learning over time and an increase in the teacher's perceptions of inquiry. What can be observed during the three years of the study is that teachers developed an increasingly evidence based practice.

Combined, the three final multidimensional complex system visualizations we designed inform and add insight to the outcomes and findings of the design based study. For example, as the teachers designed and undertook more technology rich, discipline based inquiry with students in the classroom, students reported using technology more frequently and for more complex tasks. Overall, summarizing and visually representing the findings from the student and teacher surveys using multidimensional complex system visualizations provided a means to better understand changes in the system over time that were not accessible to us or the teachers using tables of data, 
bar charts or line graphs. When we used the multidimensional complex system visualization to explore the implications of the findings with educators in the school, they were able to observe the relationship over time between their designs and students' learning. For example, by examining the findings on complexity and frequency of technology use, the teachers were able to observe the connection between their expectations and task design, and students technological ability and frequency of use. The limitations of the visual representations are that they do not convey the precision of the numerical data nor the statistical analysis and results. The visual representations compliment the numerical representations of descriptive data.

\section{Conclusion}

Information and data are becoming more complex and more abundant as technology is used to communicate, to collaborate, and to connect with each other. Increasingly, educators and researchers are charged with collecting and interpreting large and complex data sets (e.g., Designbased research and learning analytics). To better understand the ways in which a complex system is changing, adapting, and learning, the analysis and representation of research findings requires thoughtful synthesis and effective visual communication. The use of visuals and other means to classify, sort, and present findings can enhance and make accessible the patterns and trends in longitudinal data thus making the findings more meaningful. Choices of form, color, annotations, and statistical overlays can greatly contribute to better conveying the results of quantitative longitudinal studies. A well-designed and well-constructed graphic can provide a means for effective communication of study findings. Field tests with the multidimensional complex system visualizations we designed have been undertaken with teachers and other researchers, at professional presentations and academic conferences as well as in the courses we teach. User feedback demonstrates that diverse audiences find our multidimensional complex system visualizations to be more meaningful for understanding changes over time in a system on multiple dimensions than bar charts or line graphs, which supports our working hypothesis. Our future research will further test our hypothesis, that carefully crafted visualizations convey longitudinal research findings more effectively to broader audiences than do bar charts or line graphs, using empirical methods. Few educational research studies draw upon the information graphics literature for developing meaningful visualizations. In this paper, we shared our processes for following Unwin (2008), Spence (2006) and Ware (2012) to create visualizations that helped communicate our findings more effectively to both academic audiences and a broader general audience. Like Carroll's (1865/2004) Alice, the pictures we created with our multidimensional complex system visualizations are 'useful' for explaining our data. Educational researchers can draw upon our processes to develop their own pictures of data using our multidimensional complex system visualizations that better communicate their findings to a variety of audiences.

\section{References}

Barab, S. (2006). Design-based research: A methodological toolkit for the learning scientist. In R. K. Sawyer (Ed.), The Cambridge handbook of the learning sciences (pp. 153-269). Cambridge, NY: Cambridge University Press.

Berlin, D. F., \& White, A. L. (2012). A longitudinal look at attitudes and perceptions related to the integration of mathematics, science, and technology education. School Science \& Mathematics, 112(1), 20 30. doi:10.1111/j.1949-8594.2011.00111.x

Braden, R. A. (1996). The case for linear instructional design and development. Education Technology, $36(2), 5-23$.

Bulfin, S., Henderson, M., Johnson, N. F., \& Selwyn, N. (2014). Methodological capacity within the field of "educational technology" research: An initial investigation. British Journal of Educational Technology, online first. doi:10.1111/bjet.12145 
Carroll, L. (2004). Alice's adventures in Wonderland \& through the looking-glass. London: CRW Publishing. (Original work published 1865).

Collins, A., Joseph, D., \& Bielaczyc, K. (2004). Design research: Theoretical and methodological issues. Journal of the Learning Sciences, 13(1), 15-42. doi:10.1207/s15327809j1s1301_2

Craig, A., Lang, C., \& Fisher, J. (2008). Twenty years of girls into computing days: Has it been worth the effort? Journal of Information Technology Education: Research, 7, 339-353. Retrieved from http://www.jite.org/documents/Vol7/JITEv7p339-353Craig393.pdf

Creswell, J. W. (2004). Research design: Qualitative, quantitative, and mixed method approaches (Vol. 2). Thousand Oaks, CA: Sage Publications.

De Villiers, M. R. (2007). An action research approach to the design, development and evaluation of an interactive e-learning tutorial in a cognitive domain. Journal of Information Technology Education, 6, 455-479. Retrieved from http://www.jite.org/documents/Vol6/JITEv6p455-479deVilliers225.pdf

Friendly, M., \& Denis, D. (2005). The early origins and development of the scatterplot. Journal of the History of the Behavioral Sciences, 42(2), 103-130. doi: 10.1002/jhbs.20078

Galileo Educational Network. (2014). What is inquiry? Retrieved October 18, 2014, from http://galileo.org/teachers/designing-learning/articles/what-is-inquiry/

Huck, S. W. (2011). Reading statistics and research (6th ed.). Boston, MA: Pearson.

Jacobsen, M., Saar, C., \& Friesen, S. (2010). A report on the personalized learning initiative at Calgary Science School. Calgary, AB: Galileo Educational Network.

John Snow (physician). (2014, December 11). In Wikipedia, The Free Encyclopedia. Retrieved December 11, 2014, from http://en.wikipedia.org/w/index.php?title=John_Snow_physician)\&oldid=637634808

Lemke, C. (2005). A range of use: Technology in learning. OnCue Journal, Winter. Retrieved from http://learntech.ties.k12.mn.us/sites/d4d7a5a1-f96a-4856-bbc7$4 \mathrm{f} 9 \mathrm{c} 4 \mathrm{c} 8 \mathrm{~d} 1 \mathrm{~b} 88$ /uploads/RangeofUseLemke.pdf

Lemke, C., \& Coughlin, E. (2000). enGauge: A framework for effective technology use in school, brochure. The digital age, the digital age learning, the digital age learning organization. Los Angeles, CA: North Central Regional Educational Laboratory.

McKenney, S., \& Reeves, T. C. (2013). Systematic review of design-based research progress: Is a little knowledge a dangerous thing? Educational Researcher, 42(2), 97-100. doi:10.3102/0013189X12463781

McLaren, I. A. M. (2012). The use of quantitative and qualitative methods in the analysis of academic achievement among undergraduates in Jamaica. International Journal of Research \& Method in Education, 35(2), 195-216. doi:10.1080/1743727X.2012.686229

Pousman, Z., Stasko, J. T., \& Mateas, M. (2007). Casual information visualization: Depictions of data in everyday life. IEEE Transactions on Visualization and Computer Graphics, 13(6), 1145-1152. doi:10.1109/TVCG.2007.70541

Rogers, S. (2013). John Snow's data journalism: The cholera map that changed the world. Retrieved October 18, 2014, from http://www.theguardian.com/news/datablog/2013/mar/15/john-snow-cholera-map

Rosling, H. (2006). Stats that reshape your worldview [Video on TED.com.] Retrieved from http://www.ted.com/talks/hans_rosling_shows the best_stats_you_ve_ever_seen.html

Rosling, H. (2012a). Gapminder: For a fact-based world view. Retrieved from http://www.gapminder.org/

Rosling, H. (2012b). Religions and babies [Video on TED.com.] Retrieved from http://www.ted.com/talks/hans_rosling_religions and babies.html

Shea, N. A., \& Duncan, R. G. (2013). From theory to data: The process of refining learning progressions. Journal of the Learning Sciences, 22(1), 7-32. doi:10.1080/10508406.2012.691924 
The Use of Graphics to Communicate Findings

Skyjie. (2012, January 9). A guide to the psychology of color in logo design. Retrieved from http://skyje.com/color-in-logo-design/

Spence, R. (2006). Information visualization: Design for interaction (2nd ed.). New York: Prentice Hall.

Tufte, E. R. (2001). The visual display of quantitative information (2nd ed.). Cheshire, CT: Graphics Press.

Unwin, A. (2008). Good graphics? In Handbook of data visualization (pp. 57-78). Springer Berlin Heidelberg. Retrieved from http://link.springer.com.ezproxy.lib.ucalgary.ca/chapter/10.1007/978-3-540$\underline{33037-0 \quad 3}$

Ware, C. (2012). Information visualization: Perception for design (3rd ed.). Waltham, MA: Morgan Kaufmann.

William Playfair. (2014, November 20). In Wikipedia, The free encyclopedia. Retrieved December 11, 2014, from http://en.wikipedia.org/w/index.php?title=William_Playfair\&oldid=555905527

Yildiz, A. (2012). Prospective teachers' comprehension levels of special relativity theory and the effect of writing for learning on achievement. Australian Journal of Teacher Education, 37(12).

\section{Appendix A}

Table 2: Students' Frequency of Use Survey Results

\begin{tabular}{|c|c|c|c|c|c|c|c|c|}
\hline $\begin{array}{l}\text { Q4: How often do } \\
\text { you use: }\end{array}$ & Mean & SD & Mean & SD & Mean & SD & $F(2,448)$ & $\begin{array}{r}\text { Cognitive } \\
\text { Difficulty } \\
\text { Rank }\end{array}$ \\
\hline $\begin{array}{l}\text { the internet to look } \\
\text { up information } \\
\text { about people, } \\
\text { things, or ideas }\end{array}$ & 1.9 & 0.8 & 1.7 & 0.7 & 1.5 & 0.6 & $10.1^{*}$ & 3 \\
\hline $\begin{array}{l}\text { iPods and other } \\
\text { MP3 players }\end{array}$ & 2.3 & 1.4 & 2.3 & 1.5 & 2.1 & 1.5 & 0.9 & 3 \\
\hline $\begin{array}{l}\text { digital video came- } \\
\text { ras and/or digital } \\
\text { cameras }\end{array}$ & 2.7 & 1.2 & 3.0 & 1.1 & 2.6 & 1.1 & $3.8^{*}$ & 3 \\
\hline $\begin{array}{l}\text { digital voice re- } \\
\text { corders? }\end{array}$ & 2.8 & 1.1 & 3.3 & 1.1 & 3.1 & 1.1 & 7.6* & 3 \\
\hline $\begin{array}{l}\text { the Internet to } \\
\text { download music }\end{array}$ & 3.5 & 1.4 & 3.8 & 1.3 & 3.6 & 1.4 & 2.0 & 3 \\
\hline $\begin{array}{l}\text { interactive and col- } \\
\text { laborative Internet } \\
\text { places such as } \\
\text { myspace.com, } \\
\text { del.icio.us or } \\
\text { youtube }\end{array}$ & 2.7 & 1.2 & 2.5 & 1.3 & 2.3 & 1.3 & $1.7 *$ & 4 \\
\hline iChat & 2.8 & 1.6 & 2.9 & 1.7 & 2.5 & 1.7 & 2.6 & 4 \\
\hline iMovie & 2.7 & 1.0 & 3.0 & 1.0 & 2.8 & 0.9 & $3.8^{*}$ & 4 \\
\hline
\end{tabular}




\begin{tabular}{|c|c|c|c|c|c|c|c|c|}
\hline $\begin{array}{l}\text { Q4: How often do } \\
\text { you use: }\end{array}$ & Mean & SD & Mean & SD & \multicolumn{2}{|c|}{$\underline{2009}$} & $F(2,448)$ & $\begin{array}{r}\text { Cognitive } \\
\text { Difficulty } \\
\text { Rank }\end{array}$ \\
\hline GarageBand & 3.2 & 1.1 & 3.2 & 0.9 & 2.9 & 0.8 & $3.2^{*}$ & 4 \\
\hline iWeb & 4.3 & 1.0 & 4.5 & 0.9 & 4.6 & 0.8 & $4.8^{*}$ & 4 \\
\hline $\begin{array}{l}\text { the Internet to col- } \\
\text { laborate with a } \\
\text { group or team }\end{array}$ & 2.6 & 1.1 & 3.0 & 1.4 & 2.5 & 1.1 & $5.7^{*}$ & 5 \\
\hline $\begin{array}{l}\text { geography soft- } \\
\text { ware such as } \\
\text { GoogleEarth }\end{array}$ & 3.1 & 0.9 & 3.7 & 0.9 & 3.6 & 1.0 & $24.8^{*}$ & 5 \\
\hline $\begin{array}{l}\text { games on a com- } \\
\text { puter }\end{array}$ & 1.9 & 0.8 & 2.3 & 1.1 & 2.4 & 1.1 & $9.2 *$ & 7 \\
\hline $\begin{array}{l}\text { drawing, painting } \\
\text { or graphics pro- } \\
\text { grams }\end{array}$ & 3.5 & 1.1 & 2.8 & 0.9 & 2.5 & 0.9 & $31.2^{*}$ & 8 \\
\hline spreadsheets & 3.9 & 0.9 & 3.6 & 1.0 & 3.8 & 1.0 & $5.6 *$ & 8 \\
\hline $\begin{array}{l}\text { modeling software } \\
\text { such as SketchUp }\end{array}$ & 3.4 & 1.3 & 3.5 & 1.1 & 3.5 & 1.2 & 0.4 & 9 \\
\hline $\begin{array}{l}\text { animation soft- } \\
\text { ware? }\end{array}$ & 4.1 & 1.2 & 4.0 & 1.2 & 3.5 & 1.3 & 10.9* & 9 \\
\hline $\begin{array}{l}\text { interactive geome- } \\
\text { try software }\end{array}$ & 4.4 & 1.0 & 4.1 & 1.0 & 3.6 & 0.9 & $24.8^{*}$ & 9 \\
\hline $\begin{array}{l}\text { simulation soft- } \\
\text { ware? }\end{array}$ & 4.2 & 1.1 & 4.4 & 0.9 & 4.1 & 1.1 & $3.8^{*}$ & 9 \\
\hline Year & & & & & & & & \\
\hline 2007 & & & & & & & & \\
\hline 2008 & & & & & & & & \\
\hline 2009 & & & & & & & & \\
\hline $\begin{array}{l}* \text { indicates a signifi } \\
p<.05\end{array}$ & nt stati & & & & & & & \\
\hline
\end{tabular}




\section{Appendix B}

Table 3: Teacher survey data 2008 and 2009

\begin{tabular}{|c|c|c|c|c|c|}
\hline \multirow{2}{*}{\multicolumn{2}{|c|}{ Question }} & \multicolumn{2}{|c|}{2008} & \multicolumn{2}{|c|}{ 2009* } \\
\hline & & Mean & SD & Mean & SD \\
\hline \multirow{7}{*}{ 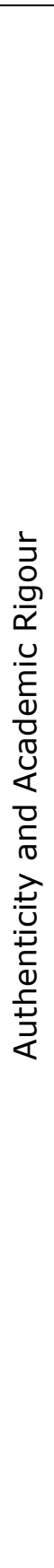 } & $\begin{array}{l}\text { Design: I strive to design tasks, } \\
\text { activities and lessons that lead } \\
\text { students to acquire, create, apply } \\
\text { and understand knowledge across } \\
\text { subject disciplines. }\end{array}$ & 1.5 & 0.53 & 1.11 & 0.33 \\
\hline & $\begin{array}{l}\text { Performance: In my class, stu- } \\
\text { dents see a link between the qual- } \\
\text { ity of products, performances, and } \\
\text { exhibitions they produce and con- } \\
\text { sequences that they consider to } \\
\text { be personally important. }\end{array}$ & 1.63 & 0.52 & 1.11 & 0.33 \\
\hline & $\begin{array}{l}\text { Challenge: I strive to challenge } \\
\text { students to use methods of in- } \\
\text { quiry central to one or more disci- } \\
\text { plines. }\end{array}$ & 1.75 & 0.71 & 1.44 & 0.53 \\
\hline & $\begin{array}{l}\text { Worthy: I provide students with a } \\
\text { wide range of activities that call } \\
\text { on them to work with content and } \\
\text { processes that have been identi- } \\
\text { fied as worth knowing and worth } \\
\text { mastering. }\end{array}$ & 1.75 & 0.46 & 1.44 & 0.53 \\
\hline & $\begin{array}{l}\text { Beyond: In my class, the inquiry } \\
\text { work that students undertake em- } \\
\text { anates from questions, problems, } \\
\text { issues or ideas that exists beyond } \\
\text { the "classroom walls." }\end{array}$ & 1.88 & 0.64 & 1.44 & 0.53 \\
\hline & $\begin{array}{l}\text { Inter-disciplinary: I work to de-- } \\
\text { sign tasks, activities and lessons } \\
\text { in such a way that students have } \\
\text { a personal and positive stake in, } \\
\text { and care about, the success of } \\
\text { other students as well as their } \\
\text { own success. }\end{array}$ & 1.88 & 0.35 & 1.22 & 0.44 \\
\hline & $\begin{array}{l}\text { Create: I regularly involve stu- } \\
\text { dents in creating products that will } \\
\text { be of use to other students, read } \\
\text { by other students, or viewed by } \\
\text { other students. }\end{array}$ & 1.88 & 0.99 & 1.67 & 0.71 \\
\hline
\end{tabular}




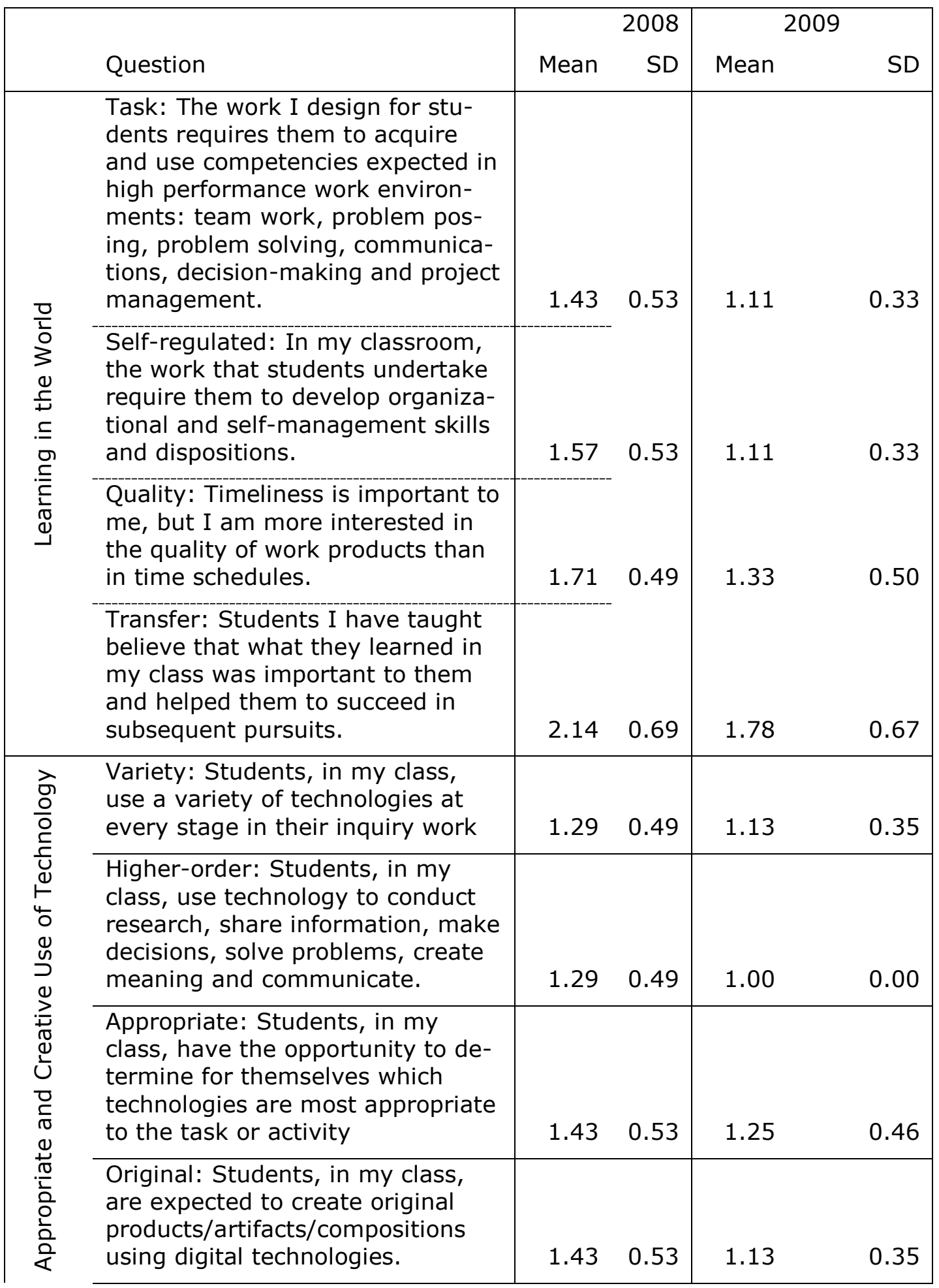




\begin{tabular}{|c|c|c|c|c|c|}
\hline \multirow{2}{*}{\multicolumn{2}{|c|}{ Question }} & \multicolumn{2}{|r|}{2008} & \multicolumn{2}{|r|}{2009} \\
\hline & & Mean & SD & Mean & SD \\
\hline \multirow{8}{*}{ 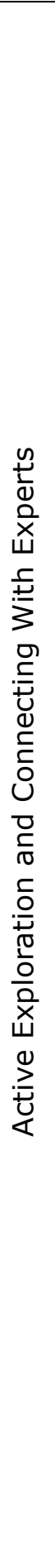 } & $\begin{array}{l}\text { Value: I usually try to link what I } \\
\text { ask students to do to a product, } \\
\text { performance, or exhibition of val- } \\
\text { ue to the student. }\end{array}$ & 1.67 & 0.52 & 1.38 & 0.52 \\
\hline & $\begin{array}{l}\text { Connection: Students usually see } \\
\text { a clear connection between what } \\
\text { they are doing and what they are } \\
\text { expected to produce. }\end{array}$ & 1.67 & 0.52 & 1.50 & 0.53 \\
\hline & $\begin{array}{l}\text { Diversity: I try to personalize } \\
\text { products so that the different } \\
\text { types of student interests are re- } \\
\text { sponded to even when students } \\
\text { are working on the same product } \\
\text { or activity. }\end{array}$ & 1.67 & 0.52 & 1.88 & 0.64 \\
\hline & $\begin{array}{l}\text { Engagement: I operate on the as- } \\
\text { sumption that most of the varia- } \\
\text { bility in student engagement in } \\
\text { my classroom has to do with the } \\
\text { way the schoolwork I provide for } \\
\text { students is designed. }\end{array}$ & 2 & 1.26 & 1.63 & 0.74 \\
\hline & $\begin{array}{l}\text { Field Based: Students, in my } \\
\text { class, spend significant amounts } \\
\text { of time doing field work, labs, in- } \\
\text { terviews, studio work, workshops } \\
\text { (writing workshops, literature cir- } \\
\text { cles), problem solving (in mathe- } \\
\text { matics), etc. }\end{array}$ & 2 & 0.89 & 1.50 & 0.76 \\
\hline & $\begin{array}{l}\text { Pride: Students in my class place } \\
\text { a great deal of personal value on } \\
\text { and take pride in the products and } \\
\text { performances they are asked to } \\
\text { produce. }\end{array}$ & 2 & 0.63 & 2 & 0.63 \\
\hline & $\begin{array}{l}\text { Questions: Students, in my class, } \\
\text { can easily answer questions about } \\
\text { what they are doing and why they } \\
\text { are doing it. }\end{array}$ & 2.5 & 0.84 & 1.63 & 0.52 \\
\hline & $\begin{array}{l}\text { Experts: The tasks and activities } \\
\text { that the students in my class un- } \\
\text { dertake require them to connect } \\
\text { with, observe and interact with } \\
\text { adult experts other than me. }\end{array}$ & 2.67 & 1.37 & 2.13 & 0.99 \\
\hline
\end{tabular}




\section{Biographies}

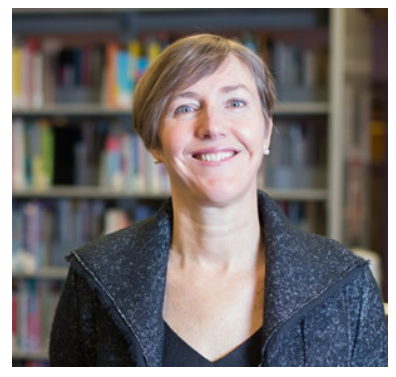

Krista Francis is an assistant professor and the Imperial Oil Science Technology Engineering and Mathematics (IOSTEM) Director at the Werklund School of Education, University of Calgary. Krista uses design-based methods to study teachers' STEM knowledge for teaching.

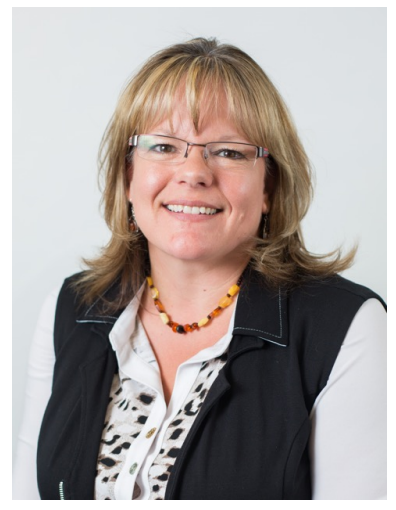

Michele Jacobsen is the Associate Dean, Graduate Programs, Werklund School of Education, University of Calgary. Michele uses designbased research to study technology-enabled learning in school and post-secondary classrooms. Michele draws upon the learning sciences to study how teachers design participatory learning environments that sponsor knowledge building, intellectual engagement and assessment as learning.

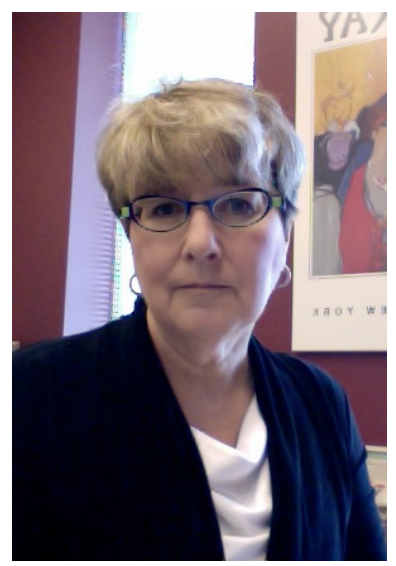

Sharon Friesen is the Vice Dean and the Associate Dean of Professional and Community Engagement in the Werklund School of Education at the University of Calgary. She is also the President of the Galileo Educational Network. Her research interests include the ways in which K-12 educational structures, curriculum, and learning need to be reinvented for a knowledge/learning society. She draws upon the learning sciences to study (i) the promotion of deep intellectual engagement, (ii) the ability to create learning environments that require sustained work with ideas, and (iii) the pervasiveness of networked digital technologies that open up new ways of knowing, leading, teaching, working, and living in the world. 